1st International Conference - Global Ethics - Key of Sustainability (GEKoS) | May 15th, 2020 | Bucharest, Romania

\title{
Mobbing at Work and the Impact of Employee Performance
}

\author{
Ciprian PETRESCU, Iulia MANGHIUC
}

https://doi.org/10.18662/lumproc/gekos2020/28

How to cite: Petrescu, C., \& Manghiuc, I. (2020). Mobbing at Work and the Impact of Employee Performance. In A. Grigorescu \& V. Radu (vol. ed.), Lumen Proceedings: Vol. 11. 1st International Conference Global Ethics - Key of Sustainability (GEKoS) (pp. 273-282). Iasi, Romania: LUMEN Publishing House. https://doi.org/10.18662/lumproc/gekos2020/28 


\title{
Mobbing at Work and the Impact of Employee Performance
}

\author{
Ciprian PETRESCU1', Iulia MANGHIUC2* \\ Abstract
}

The psychological abuse on a person at work it is called mobbing. This phenomenon it is one that influences the organizational culture, in a negative sense, reducing job satisfaction and creating a tense atmosphere. The consequences of this phenomenon affect the climate within the organization, the performance of the employees and by default, the objectives of the organization. The purpose of this article is to define and to determine the types and cases in which the phenomenon of mobbing occurs. We also analyzed the existing legislation regarding the protection of the employees from this phenomenon.

Keywords: mobbing; job; ethics; organization.

\footnotetext{
${ }^{1}$ University of Valahia, Targoviste, Romania, petrescucipri@yahoo.com..

${ }^{2}$ University of Valahia, Targoviste, Romania, julia m 21@yahoo.com.

* Corresponding author. 


\section{Introduction}

The term mobbing represents the psychological stress exercised on an individual in the workplace [11]. This, in turn, involves phenoma such as psychological terror, agrression, hostile behaviour, trauma, uncivilized behaviour, emotional violence or harassment, manifesting only in the activity environment. All these concepts have in common the humiliation and diminution of a person's prestige. Harassment can be any comment, behavior, gesture that discredits, offends, intimidates, humiliates and isolates, not to mention sexual or racial comments [6].

The article intends to highlight the profoundness of the phenomenon that take place within an organization, in the public or private domain, investigations aiming to the aspects related to the phenomenon called mobbing, its implications within the organization and the repercussions it registers.

We will have as a benchmark the need of individuals to maintain their capacity for performance. This involves that any defensive strategy requires experience, a well-defined psychological profile and knowledge of the legislative background in the field.

As a final point, we will identify methods meant to be applied, so that they eliminate the distortions generated by the practice of the mobbing phenomenon simultaneously respecting the ethical and legislative norms within the field.

\section{Problem Statement}

The phenomenon of mobbing is influenced by certain factors related to the personality of individuals, such as character, temperament or education received [6]. This phenomenon, which is a complex one, can be counteracted by an organizational development policy, which should include the encouragement of cooperation and collegiality, the promotion of teamwork or the correctness it manifests in the activity carried out.

The research intends to highlight the impact of the behaviours manifested by individuals within the organization and the repercussions on the aggressed person, organization, family, expected performances, etc. 
Ciprian PETRESCU et al. | Lumen Proceedings 11 | GEKoS2020

\section{Research Questions/Aims of the research}

Starting with the questions that underline this scientific approach, the main objectives of this research are:

- identifying the different forms in which mobbing manifests itself, as well as the hypostases in which it acts;

- identifying the types of people who may fall prey to this phenomenon;

- identifying the actors who apply pressures characteristic of psychological harassment;

- identifying those ways to prevent/ combat mobbing;

- identifying the legislative instruments necessary to combat harassment in the workplace;

- identifying the norms of behavioral ethics within the organizations.

The hypotheses for the study to be performed, will be oriented as follows:

- Does the legislative framework effectively address the phenomenon of mobbing?

- Does mobbing directly influence employee performance?

- Does the ethical formalization represent a desideratum that can combat mobbing?

\section{Research Methods}

In our research approach we used the qualitative method, in which we had the main tools the observation and analysis of documents / data. For this topic, during February-March of the current year, we undertook a study conducted on a sample of 137 subjects from Bucharest-Ilfov aged 20-45 years, employed in institutions / organizations, in the public and private domain, holding management and executive positions.

The research was conducted based on the interview and aimed to identify the perceptions, attitudes and behaviors of employees and employers in relation to social relations in the workplace.

\section{Findings}

The initiator of this field is the Swedish professor Heinz Leymann [5], who in 1986 wrote the book Mobbing-Psychological violence at work. His 
initial research was based on case studies of nurses who committed suicide or attempted suicide due to the events that took place at work [5].

Analyzing the relationship between the aggressor and the victim, Heinz Leymann divided the specific actions of mobbing into 5 categories [5]: limiting the victim's expression, isolation, disregard, professional discredit and harm to the health of the person concerned [10]. Through his studies Professor Leymann came to the conclusion that the defining factors in classifying some behaviors as mobbing are the frequency and the period in which the actions take place. Thus, they must be maintained for a period of at least six months, the frequency being at least twice a week. For a broader view of the types of mobbing or the effects that this phenomenon has on the target, we will present schematically in what forms we can meet it in Table 1, Table 2 and Table 3.

The most common form of mobbing is the downward vertical mobbing and describes the relationship from superior to subordinate, relationship with an unequal balance of forces. In this situation, the manager may perceive the subordinate as a competitor, as a person who unbalances him emotionally and makes him lose self-confidence.

In the same order of ideas, continuing with the interrogations that are the basis of this scientific approach and based on the analysis of the documents, we consider opportune the fallowing representative explanations for the present research: Who can fall prey to mobbing?

In general, the target groups that may be victims of the mobbing phenomenon are composed of a senior-level (top performers) who belong to different spheres of activity, but there also of those who enjoy popularity within the company.

Compared to the first category, even the superior - in the aria of such a competent / very intelligent employee - can often feel overshadowed by the performance of the subordinate, becoming envious and may resort to harassment or mental torture. In the case of the second category, superiors will try to underestimate his image and strengths through the same nonlethal weapons of harassment or mental torture, given that while our employee enjoys a good image in the middle of the team, the superior feels that his authority can be diminuend within the group. In these situations, some employees become vulnerable (shy, anxious, fearful, docile employees), and others are extroverted and adopt an optimistic and positive attitude. 
Table 1. Types of mobbing and its effects depending on hypotheses and number of people[6]

\begin{tabular}{|c|c|c|c|c|}
\hline \multicolumn{5}{|c|}{ Mobbing } \\
\hline \multicolumn{3}{|c|}{ Hypotheses } & \multicolumn{2}{|c|}{ Number of people } \\
\hline Vertical & Horizontal & Mixed & Individually & Collective \\
\hline $\begin{array}{l}\text { Ascending - the } \\
\text { manager's lack of } \\
\text { trust and } \\
\text { knowledge can be } \\
\text { charged by one or } \\
\text { more employees; } \\
\text { Descending - the } \\
\text { manager can } \\
\text { perceive the } \\
\text { subordinate as a } \\
\text { competitor, as a } \\
\text { person who } \\
\text { unbalances him } \\
\text { emotioanally and } \\
\text { makes him lose } \\
\text { self-confidence }\end{array}$ & $\begin{array}{l}\text { The level of } \\
\text { the icipient } \\
\text { rivalry - the } \\
\text { harasser } \\
\text { tries to get } \\
\text { the } \\
\text { opponent } \\
\text { out of the } \\
\text { race for } \\
\text { promotion; } \\
\text { The level of } \\
\text { the } \\
\text { consumed } \\
\text { rivalry - the } \\
\text { harasser } \\
\text { takes } \\
\text { revenge for } \\
\text { the failure } \\
\text { suffered }\end{array}$ & $\begin{array}{l}\text { Between } \\
\text { people on } \\
\text { the same } \\
\text { hierarchical } \\
\text { level - } \\
\text { shared, } \\
\text { ignored } \\
\text { and } \\
\text { assumed } \\
\text { by the } \\
\text { superior }\end{array}$ & $\begin{array}{l}\text { An act of } \\
\text { marginalization }\end{array}$ & $\begin{array}{l}\text { Organizational } \\
\text { strategy, } \\
\text { which aims to } \\
\text { reduce the } \\
\text { workforce }\end{array}$ \\
\hline
\end{tabular}

Table 2. Types of mobbing and its effects depending on severity and double

\begin{tabular}{|c|c|c|c|}
\hline \multicolumn{4}{|c|}{ Mobbing } \\
\hline \multicolumn{3}{|c|}{ Severity } & \multirow{2}{*}{ Double } \\
\hline Grade 1 & Grade 2 & Grade 3 & \\
\hline $\begin{array}{l}\text { menages to } \\
\text { withstand } \\
\text { and adapt } \\
\text { to the same } \\
\text { or a similar } \\
\text { job }\end{array}$ & $\begin{array}{l}\text { cannot resist or get } \\
\text { out immediately of the } \\
\text { situation, suffers from } \\
\text { psychological or } \\
\text { physical incapacity, } \\
\text { temporary or lasting, } \\
\text { and has difficulty } \\
\text { reintegrating }\end{array}$ & $\begin{array}{l}\text { is not able to reintegrate } \\
\text { and the effects are } \\
\text { extremely devastating, so } \\
\text { most of the time its } \\
\text { reintegration / } \\
\text { rehabilitation must be } \\
\text { supported by specialized } \\
\text { treatment. }\end{array}$ & $\begin{array}{l}\text { it involves } \\
\text { harassment at } \\
\text { work and } \\
\text { deprivation of } \\
\text { family's } \\
\text { understanding } \\
\text { and help }\end{array}$ \\
\hline
\end{tabular}


Ciprian PETRESCU et al. | Lumen Proceedings 11 | GEKoS2020

Table 3. Types of mobbing and its effects depending on the phenomenon's manifestation and the effects on the target

\begin{tabular}{|c|c|c|}
\hline \multicolumn{3}{|c|}{ Mobbing } \\
\hline \multicolumn{2}{|c|}{ Phenomenon's manifestation } & \multirow[b]{2}{*}{ Effects on the target } \\
\hline Strategic & $\begin{array}{l}\text { Emotional or } \\
\text { relational }\end{array}$ & \\
\hline $\begin{array}{l}\text { Stuff } \\
\text { restructuring } \\
\text { method }\end{array}$ & $\begin{array}{l}\text { Envy is manifested } \\
\text { among colleagues }\end{array}$ & $\begin{array}{l}\text { Affects the ability to communicate } \\
\text { properly; } \\
\text { Affects the possiblity of maintaining social } \\
\text { contacts; } \\
\text { Affects the victim's ability to maintain his } \\
\text { or her reputation; } \\
\text { Affects the occupational situation; } \\
\text { Affects physical health. }\end{array}$ \\
\hline
\end{tabular}

\section{Who can exert the pressures characteristic of mobbing?}

Normally, mobbing is the result of interaction between the aggressor and the victim, the organization, the triggering event and external factors[6]. Experts claim that most of the time the aggressors how such behavior either out frustration (in this cases the case arises: the aggressor was a victim in turn?) or they express themselves and can achieve the emotional balance they need. Sometimes, the act of aggression involves a hereditary, learned behavior, and most of the time this is the aggressor's first reaction to frustration.

Among the most commonly used tactics, aggressors often invoke false accusations for acts that the victim did not even commit; one of the nonverbal techniques of intimidation used by the aggressor is to fix his gaze accompanied by a frown; the victim's ideas or feelings are often disqualified in public; adopting an attitude of isolation or total ignorance of the victim; underestimation of the victim, even if he obtained exemplary results; adopting a set of rules that the aggressor himself did not master [6].

\section{How can we fight mobbing?}

In face of any repetitive aggression, and which was not an isolated incident, the subject has a number of means at his disposal to support him [6]. One of the forms is the prevention by awareness that a mobbing behavior is manifested on him, even if it is an incipient phase, by adopting a positive, optimistic attitude or by personal development exercises (participation in various courses / conferences on this topic) [6]. 
The employer also has an important role to play in combating this phenomenon without making fun of and not encouraging these behaviors. At the same time, it can implement various training on mobbing, so that employees are aware of the threats they are subjected to. Moreover, the analysis of the periodic psychological state of the employees can identify the predispositions of those liable to become aggressors.

\section{Ethical issues within organizations}

Ethical norms within any organization can be violated by internal staff through behaviors that lead to integrity problems of other employees [6], but also affect the institution, creating a reputation that leaves much to be desired. Thus, some actions that contravene the ethical norms carried out by the company's staff, from any hierarchical level, may be the violation of the rules established by the institution or the violation of rights of any kind of the other employees [6].

Also, some people may launch lies, rumors [6] or even exaggerations in order to create a negative image. The category of unethical behavior also includes the attribution of merits for certain achievements or ideas, which are not allowed to be used.

\section{Current legislative framework}

In Romania, mobbing has not been assigned a specific source of law issued by a competent public authority and that contains norms, rules, the application of which, in the end, is guaranteed by the state [6]. However, there are some provisions[6] which include certain fundamental principles, rights and obligations that sanction the phenomenon of mobbing, seen as a form of discrimination or violation of equal opportunities, and which, in the end, is the cause of moral or material damage or injury to employees. In addition, the specialized doctrine or the unofficial sources of law bring a considerable theoretical contribution.

On the basis of the legal norms presented, related to the evidence in practice, the courts note that employees who fall into the trap of mobbing are entitled to claim moral damages from the employer, according to the provisions of Article 253 of the Labor Code, bringing various evidence, from documents to witnesses.

Even in the light of this legislative deficiency, the jurisprudence does not seem to be inactive in this area either. Numerous incidents are noticed and details both in the online environment and in the specialized doctrine. The Research Institute for Quality of Life conducted a study [3] on two representative samples from Bucharest-Ilfov, South-Muntenia, Center and 
North-West, as well as on a national representative sample of 1,200 people, population aged 18-65 years, the data collection period was April-May 2010. The research was conducted in the counties of: Bucharest, Prahova, Calarasi, Giurgiu, Brasov, Sibiu, Mures, Cluj and aimed to identify the behavior of employees and employers in relation to tense or conflicting situation between employees. Thus, in Bucharest-Ilfof, $41 \%$ of respondents say that there was such a situation in which a boss showed aggressive behavior towards subordinates, and according to the study, $8 \%$ of them fall into the phenomenon of mobbing. The study was conducted based on the interview.

Also, following our analysis with an emphasis on objective and subjective conditions that may appear as precursors of the mobbing phenomenon, tense or conflicting situations were identified between employees, starting with lack of professional appreciation and continuing with an extreme type of behavior - screaming and insults, although, at a low level. High values were recorded in the case of direct behaviors, such as humiliation from a boss. Thus, $47 \%$ of respondents say that there has been such a situation in which a boss shouts at his subordinates, and according to the data, $9 \%$ fall into the phenomenon of mobbing.

Based on the results of our study, as well as those from the Research Institute for Quality of Life, we performed a comparative analysis on the data recorded on the tense or conflicting situations between employees.

In both studies we took into consideration the identification of the behaviors characterized by insults, assigning unclear tasks, lack of professional appreciation and continuing with screams, insults and humiliation.

The research recorded approximately identical data. It seems that, at a difference of almost 10 years, the behaviors characterized by aggression persist, and the aggressors normally use the same weapons: insults, offends and humiliation. It is noteworthy that $47 \%$ of the subjects in our study and just over $40 \%$ of the respondents of the Research Institute for Quality of Life perceived such behaviors in their relationship with the employer, and just under 10\% categorized these behaviors as mobbing type, which means that, according to Heinz Leymann, were maintained for a period of at least six months and the frequency being at least twice a week.

\section{Conclusions}

In order to combat mobbing, it is necessary for this phenomenon to be primarily aware at the level of society. In order to reduce the effects of mobbing, it is necessary for the company to be informed about the impact it 
has on people within companies, and in order to report such practices, the stuff must be informed about the characteristics of mobbing. It should also be emphasized that mobbing can have serious economic consequences, even on organizations.

The ultimate goal of the aggressor, who adopts this behavior specific to the phenomenon of mobbing, is to remove the unwanted person from the organization. Thus, the aggressor attacks through different methods the actions by which the victim achieves his objectives. Consequently, the hypothesis regarding the performance of employees in the context of the use of these psychological weapons is validated, in the sense that mobbing directly influences the employees' performances.

Ethical formalization, in the form of codes of ethics, codes of conduct and internal regulations, is a desideratum that ensures the transition between the values of an organization and the law. The existence in companies of such procedures to guide behavior in case of ethical dilemmas is necessary to avoid deviation from conduct that violates moral standards.

We also easily noticed that the specifics and characteristics of the mobbing phenomenon have nothing in common with honesty, fairness, respect or responsibility.

Taking into account that a specific behavior of mobbing violates all ethical principles, we can conclude that this phenomenon, among others, is a matter of organizational ethics, and the current legislative framework requires explicit provisions to fine the specific behaviors of this phenomenon.

\section{References}

[1] Bican OL. Tipologii ale mobbingului în organizaţii. Annals of the Constantin Brâncuşi University of Târgu Jiu, Education Sciences Series [Internet] [cited 2020 April 22]. 2015; 2. Available from: http://www.utgiju.ro.

[2] Bouchard N. Rezolvarea conflictelor la serviciu. Iaşi: Editura Polirom, 2006.

[3] Cace S, Ilie S, Lambru M, Mihăilescu A, Neguț A, Popescu R, Preoteasa AM, Preotesi M, Stanciu M, Stănilă G, Tomescu C, Tufă L. Studiu asupra fenomenului de mobbing şi a unor forme de discriminare la locul de muncă în România. [cited 2020 April 15]. Available from: https://sindicatsinpen.files.wordpress.com.

[4] Călin D. Mobbingul - hărţuirea la locul de muncă. Bucureşti: Editura Universitară, 2019.

[5] Gheondea A, Ilie S, Lambru M, Mihăilescu A, Neguț A, Stanciu M, Tomescu C. Fenomene specifice de discriminare la locul de muncă: mobbing-ul. [cited 2020 April 02]. Available from: https://www.researchgate.net.

[6] Government Ordinance no. 137/2000 on the prevention and sanctioning of all forms of discrimination, Law no. 202/2002 on equal opportunities and equal 
treatment between women and men, as subsquently amended and supplimented, Council Directive 89/391/ECC of 12 June 1989 on the implementing measures to promote the improvement of workers' safety and health at work; Charter of Fundamental Rights of the European Union - fair and just working conditions, European Parliament resolution 2001/2339 on moral harassment in the workplace.

[7] Grecu E şi asociații. [cited 2020 April 05]. Available from: https://greculawyers.ro/prevederi-legislative-pe-plan-international-privindfenomenul-de-mobbing/.

[8] Kovacs P. Hărțuirea la locul de muncă. [cited 2020 April 25]. Available from: http://www.ohpedu.ro.

[9] Kowal J, Gwiazda-Sawicka G. Mobbing as a problem in management ethics. Annals Ethics in Economic Life [Internet]. 2018 [cited 2020 April 10];21(5):131-145. Available from: https://www.researchgate.net.

[10] Lazariuc C. Măsuri în prevenirea şi contracararea mobbing-ului la locul de muncă la nivelul Uniunii Europene. [cited 2020 March 30]. Available from: http://repository.utm.md.

[11] Macovei T. Ce este mobbing-ul organizațional. Revista națională de drept [Internet]. 2014 [cited 2020 March 31];6. Available from: https://ibn.idsi.md.

[12] Weinberg A, Cooper C, Sutherland VJ. Organizational Stress Management: A Strategic Approach. New York: Palgrave Macmillan, 2010.

[13] Westhues K. Workplace Mobbing in Academe: Reports from Twenty Universities. New York: Edwin Mellen Press, 2004.

[14] Zaharia EC. Mobbingul sau teroarea psihologică. [cited 2020 April 10]. Available from: https://snapromania.ro.

[15] Kuźmicz E. One in 10 teachers subject to mobbing at work, 2010. Available from: https://www.eurofound.europa.eu, [cited 2020 April 07].

[16] Leymann Inventory of Psychological Terror, Available from: http://www.antimobbing.eu/lipt.html, [cited 2020 April 10].

[17] Einarsen, Stale, Hoel, Helge The Negative Acts Questionnaire: Development, validation and revision of a measure of bullying at work, 2001, Available from: http://workplacebullying.info/coord/docs/NAQ.pdf, [cited 2020 April 10].

[18] Probleme şi dileme etice în organizații, 2012, Available from: https://resurseumane1001.wordpress.com/tag/norme-etice/, [cited 2020 April $15]$.

[19] Leymann in English. Available from: http://www.leymann.se/English/frame.html, [cited 2020 April 05]. 